\title{
Pathophysiology of Cardiorenal Syndrome Type 2 in Stable Chronic Heart Failure: Workgroup Statements from the Eleventh Consensus Conference of the Acute Dialysis Quality Initiative (ADQI)
}

\author{
Dinna N. Cruz ${ }^{a}$ Andrew A. House ${ }^{b} \cdot$ Kai M. Schmidt-Ott ${ }^{c}$. \\ Giorgio Vescovo ${ }^{\mathrm{d}} \cdot$ John A. Kellum ${ }^{\mathrm{e}} \cdot$ Claudio Ronco $^{f}$. \\ Peter A. McCullough • for the Acute Dialysis Quality Initiative \\ (ADQI) Consensus Group
}

\begin{abstract}
a Division of Nephrology-Hypertension, Department of Medicine, University of California, San Diego, San Diego, Calif., USA; 'b Division of Nephrology, London Health Sciences Centre, London, Ont., Canada; 'Department of Nephrology, Experimental and Clinical Research Center, Charité - Universitätsmedizin Berlin, and Max Delbrück Center for Molecular Medicine, Berlin, Germany; ${ }^{d}$ Department of Internal

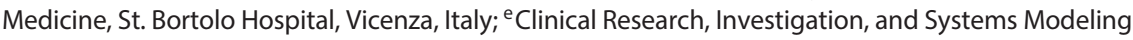
of Acute Illness Center, Department of Critical Care Medicine, University of Pittsburgh, Pittsburgh, Pa.,

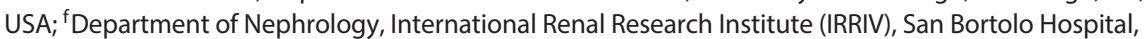
Vicenza, Italy; ${ }^{9}$ St. John Providence Health System, Warren Mich., Providence Hospitals and Medical Centers, Southfield and Novi, Mich., St. John Macomb Oakland Center, Madison Heights, Mich., St. John Hospital and Medical Center, Detroit, Mich., USA
\end{abstract}

\begin{abstract}
In cardiorenal syndrome (CRS) type 2, chronic heart failure (HF) results in the onset or progression of chronic kidney disease (CKD). Examples of CRS type 2 (CRS2) include progressive CKD resulting from chronic HF in congenital or acquired heart disease or from repeated bouts of acute decompensated HF. Animal data and clinical studies indicate that extended periods of chronic HF result in altered renal hemodynamics followed by progressive renal pathology. Experimental and clinical data indicate that CRS2 is characterized by mild to moderate proteinuria, a progressive decline of glomerular filtration rate, and an elevated expression of renal injury biomarkers. Important pathophysiological triggers of renal disease progression include chronic increases in renal venous pressure, maladaptive activation of the renin-angiotensin-aldosterone axis and the sympathetic nervous system, as well as a chronic inflammatory state. Intrarenal oxidative stress and proinflammatory
\end{abstract}


signaling precipitate structural injury, including glomerulosclerosis and tubulointerstitial fibrosis. Yet, clinical interventional trials that directly test the impact of renin-angiotensin system antagonists and $\beta$-blockers on the progression of CKD in CRS2 are lacking. Secondary analyses of trials designed to assess the impact of these agents on cardiovascular endpoints have failed to show a consistent benefit regarding renal functional parameters. In contrast, left ventricular assist device placement and cardiac resynchronization therapy in HF patients consistently improved renal function, suggesting a marked potential for reversibility in many cases of CRS2. Future research should be directed towards the evaluation of novel biomarkers to improve the diagnosis, severity grading as well as our understanding of the pathophysiology of CRS2. In addition, there is a need for interventional trials in HF patients to address long-term renal endpoints incorporating clinical information and measures of renal function as well as renal injury.

Copyright $\odot 2013$ S. Karger AG, Basel

Cardiorenal syndrome (CRS) is defined as a complex pathophysiological disorder of the heart and kidneys in which acute or chronic dysfunction in one organ may induce acute or chronic dysfunction in the other organ. All subtypes are associated with increased mortality and morbidity, with a significant impact on health resource utilization. An understanding of the specific pathophysiologic mechanisms underlying each subtype will have important implications for risk factor modification, management, and future clinical trials.

CRS type 2 (CRS2) is characterized by chronic abnormalities in cardiac function leading to kidney injury or dysfunction. As such, the temporal relationship between the heart and kidney disease is an important aspect of the definition. While observational data clearly show that chronic heart and kidney disease commonly coexist, large database studies often assemble the patient cohort based on the existence of one disease process (e.g. chronic heart failure $(\mathrm{HF})$ ) and subsequently describe the prevalence of the other (chronic kidney disease (CKD)) [1, 2]. For example, CKD has been observed in 26-63\% of CHF patients [1-3]. However, such studies are unable to determine which of the two disease processes was primary versus secondary, presenting challenges when attempting to classify patients into the CRS subtype definitions. In these situations, it has been suggested to use the term CRS 'type 2/4' [4].

\section{CRS2 in Stable Chronic Heart Failure}

In view of the above, the mere coexistence of cardiovascular disease and CKD is not sufficient to make a diagnosis of true CRS2. In the specific setting of stable $\mathrm{CHF}$, we propose the following two prerequisites to make a diagnosis of CRS2; first, that $\mathrm{CHF}$ and $\mathrm{CKD}$ coexist in the patient, and second, CHF causally underlies the occurrence or progression of CKD. The latter should be supported by both tempo- 


\begin{tabular}{|c|c|c|}
\hline Chronic HF & \multirow{6}{*}{ 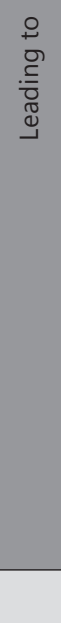 } & EITHER: New onset of CKD \\
\hline Definition & & Definition \\
\hline \multirow{4}{*}{$\begin{array}{l}\text { Symptoms typical of HF } \\
\text { Signs typical of HF } \\
\text { (HF-REF) Reduced LVEF } \\
\text { OR: } \\
\text { (HF-PEF) Normal or mildly } \\
\text { reduced EF and LV not dilated, } \\
\text { with relevant structural } \\
\text { disease and/or diastolic } \\
\text { dysfunction } \\
\text { (according to ESC, } \\
\text { ACC/AHA) }\end{array}$} & & $\begin{array}{l}\text { Albuminuria and/or GFR }<60 \mathrm{ml} / \mathrm{min} / 1.73 \mathrm{~m}^{2} \\
\text { (according to } \mathrm{KDIGO} / \mathrm{KDOQI} \text { ) }\end{array}$ \\
\hline & & OR: Progression of CKD \\
\hline & & $\begin{array}{l}\text { Sustained } \downarrow \text { eGFR of }>5 \mathrm{ml} / \mathrm{min} / 1.73 \mathrm{~m}^{2} / \text { year, or }>10 \\
\mathrm{ml} / \mathrm{min} / 1.73 \mathrm{~m}^{2} / 5 \text { years* } \\
\text { OR: sustained increase in albuminuria }\end{array}$ \\
\hline & & PLUS \\
\hline \multicolumn{3}{|c|}{$\begin{array}{l}\text { Temporal association: A documented or presumed onset of congestive heart failure } \\
\text { precedes the occurrence or progression of CKD }\end{array}$} \\
\hline \multicolumn{3}{|r|}{ and } \\
\hline \multicolumn{3}{|c|}{$\begin{array}{l}\text { Pathophysiological plausibility: The manifestation and degree of kidney disease is plausibly } \\
\text { explained by the underlying heart condition. }\end{array}$} \\
\hline
\end{tabular}

Fig. 1. Proposed definition of CRS2 in stable chronic HF. Reproduced with permission from ADQI [62].*National Collaborating Centre for Chronic Conditions. Chronic kidney disease: national clinical guideline for early identification and management in adults in primary and secondary care. London: Royal College of Physicians, September 2008.

ral association, i.e. documented or presumed onset of congestive HF temporally precedes the occurrence or progression of $\mathrm{CKD}$, and by pathophysiological plausibility, that is, the manifestation and degree of kidney disease is plausibly explained by the underlying heart condition (fig. 1). One clear example of CRS2 would be congenital heart disease and 'cyanotic nephropathy', in which the heart disease temporally precedes any kidney disease. Another would be an acute cardiac event (e.g. acute myocardial infarction) resulting in chronic left ventricular (LV) dysfunction, then followed by the onset of CKD or progression of preexisting CKD.

Heterogeneity in the human HF population and aspects unique to cyanotic heart disease make it difficult to tease out specific mechanisms for CRS2 based on human studies. Therefore, animal studies provide important insight into the pathogenesis of CRS2 by mimicking human phenotypes (table 1). Although multiple and complex mechanisms have been proposed, the predominant mechanisms include neurohormonal activation, hemodynamic factors of renal hypoperfusion and venous congestion, inflammation and oxidative stress (fig. 2). Aside from specific mechanisms, we posit that multiple episodes of acute de- 
Table 1. Animal models of heart failure and CRS2

\begin{tabular}{|c|c|c|c|c|c|}
\hline $\begin{array}{l}\text { Mecha- } \\
\text { nism }\end{array}$ & Study & Model & $\begin{array}{l}\text { Follow- } \\
\text { up days }\end{array}$ & Biochemical outcomes & Histologic outcomes \\
\hline $\begin{array}{l}\text { RAAS } \\
\text { activation }\end{array}$ & $\begin{array}{l}\text { Onozato } \\
(2007)\end{array}$ & $\begin{array}{l}\text { Salt-sensitive Dahl } \\
\text { rat HF model; } \\
\text { eplerenone and/ } \\
\text { or trandolapril }\end{array}$ & 126 & $\begin{array}{l}\text { ACEl or combination: } \\
\text { lower creatinine, lower } \\
\text { albuminuria Epl: lower } \\
\text { albuminuria }\end{array}$ & $\begin{array}{l}\text { ACEI: } \downarrow \text { glomerular sclerosis, } \\
\downarrow \text { oxidative stress } \\
\text { Epl or combination: } \downarrow \text { glomerular } \\
\text { sclerosis, } \downarrow \text { oxidative stress and } \downarrow \text { TGF- } \beta\end{array}$ \\
\hline $\begin{array}{l}\text { SNS } \\
\text { activation }\end{array}$ & Rafiq (2012) & $\begin{array}{l}\text { Rat aortic } \\
\text { regurgitation; } \\
\text { renal denervation, } \\
\text { and/or olmesartan }\end{array}$ & 180 & $\begin{array}{l}\text { Denervation lowers albu- } \\
\text { muria, plasma norepi- } \\
\text { nephrine, renal Ang2 } \\
\text { ARBlowersBNP, renalAng2 }\end{array}$ & $\begin{array}{l}\text { Denervation lessens glomerular injury } \\
\text { and oxidative stress } \\
\text { Denervation and ARB lessen further }\end{array}$ \\
\hline \multirow[t]{3}{*}{$\begin{array}{l}\text { Inflam- } \\
\text { mation, } \\
\text { fibrosis }\end{array}$} & Lu (2012) & $\begin{array}{l}\text { Mouse coronary } \\
\text { ligation; knockout } \\
\text { for LOX-1 }\end{array}$ & 21 & $\begin{array}{l}\text { LOX-1 knockout had } \\
\text { preserved GFR compared } \\
\text { with control }\end{array}$ & $\begin{array}{l}\text { LOX-1 knockout had less renal } \\
\text { expression of pro-IL- } 1 \text { b, TGF- } \beta \text {, VCAM, } \\
\text { fewer PMNs, } \downarrow \text { collagen/fibrosis }\end{array}$ \\
\hline & $\begin{array}{l}\text { Lekawanvijit } \\
(2012)\end{array}$ & $\begin{array}{l}\text { Rat coronary liga- } \\
\text { tion }\end{array}$ & 112 & $\begin{array}{l}\text { HF rats had lower GFR and } \\
\text { more albuminuria than } \\
\text { control }\end{array}$ & $\begin{array}{l}\text { HF rats had marked increases in } \\
\text { phosphorylated Smad2, KIM-1, IL- } 6 \text {, } \\
\text { TGF- } \beta \text { and CD } 68+\text { cells, with significant } \\
\text { interstitial fibrosis }\end{array}$ \\
\hline & $\begin{array}{l}\text { Entin-Meer } \\
(2012)\end{array}$ & $\begin{array}{l}\text { Rat coronary liga- } \\
\text { tion }\end{array}$ & 30 & $\begin{array}{l}\text { HF rats had lower GFR and } \\
\text { more albuminuria than } \\
\text { control }\end{array}$ & $\begin{array}{l}\text { HF rats had marked increases in KIM-1, } \\
\text { NGAL, CD3 and CD } 68+\text { cells, with } \\
\text { significant interstitial fibrosis }\end{array}$ \\
\hline
\end{tabular}

compensation of the heart or kidney may contribute to the progression of HF and CKD (fig. 3). This is suggested by data showing that the number of previous hospitalizations for HF was a strong predictor of mortality after controlling for other known risk factors for HF survival [5]. Although repeat hospitalizations may be considered a marker of disease severity, suboptimal care or poor patient compliance, repeated acute decompensation could potentially lead to modification of cardiac structure, increased fibrosis and LV modeling. Moreover, on long-term follow-up of 70 patients with dilated cardiomyopathy, frequency of HF admissions was independently associated with development of CKD (defined as estimated creatinine clearance $<60 \mathrm{ml} / \mathrm{min}$ ) [6]. Similarly, the detrimental effect of acute kidney injury episodes on the development and progression of CKD has been demonstrated in animal models and in epidemiologic studies [7].

\section{Animal Models and Pathophysiological Insights into CRS2}

In experimental $\mathrm{HF}$, there is a reduction in glomerular plasma flow, but an elevated glomerular filtration fraction due to efferent arteriolar vasoconstriction. When these changes persist for extended time periods (3-6 months in the rat 


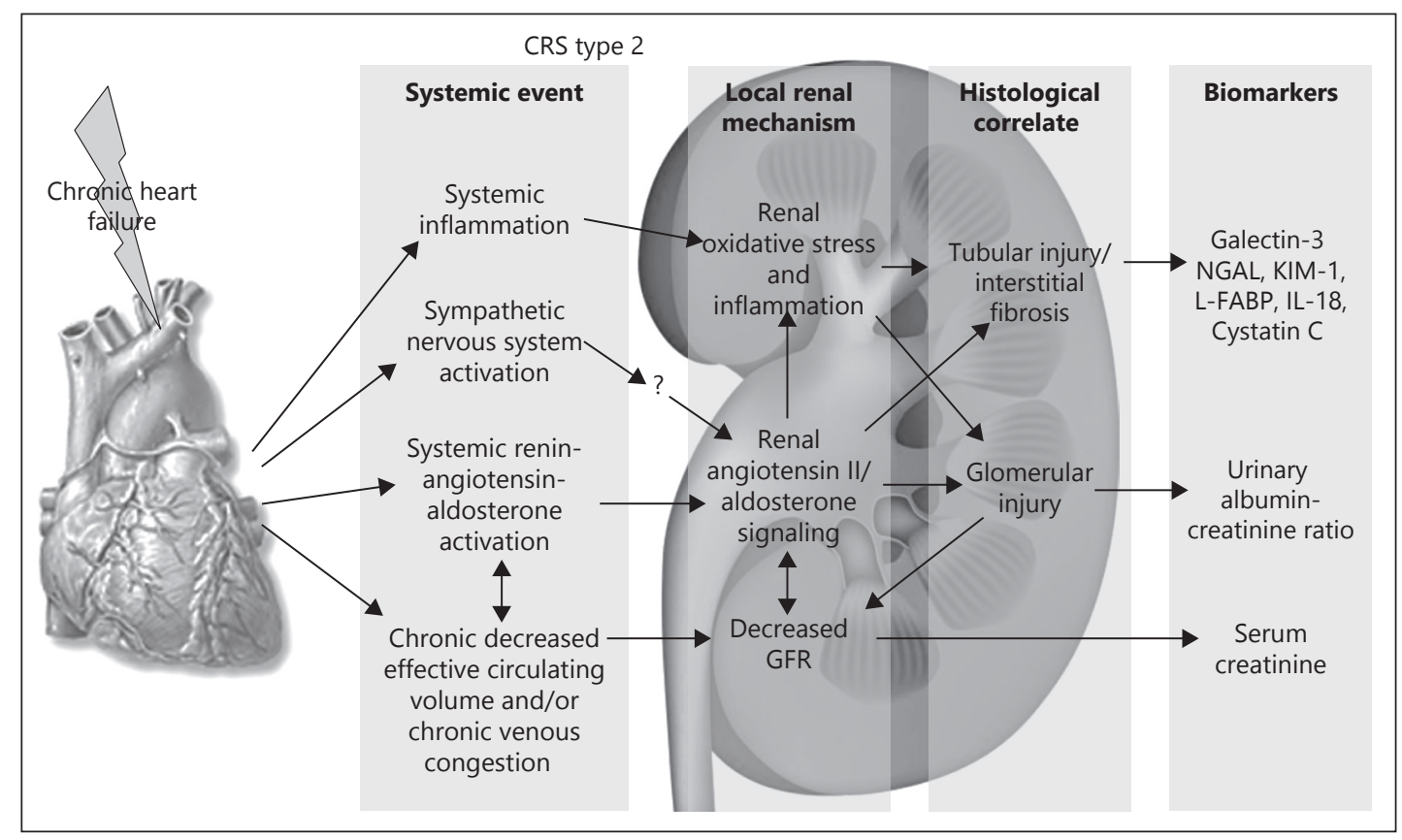

Fig. 2. Predominant pathophysiologic mechanisms of CRS2 in stable chronic HF. Reproduced with permission from ADQI [62]

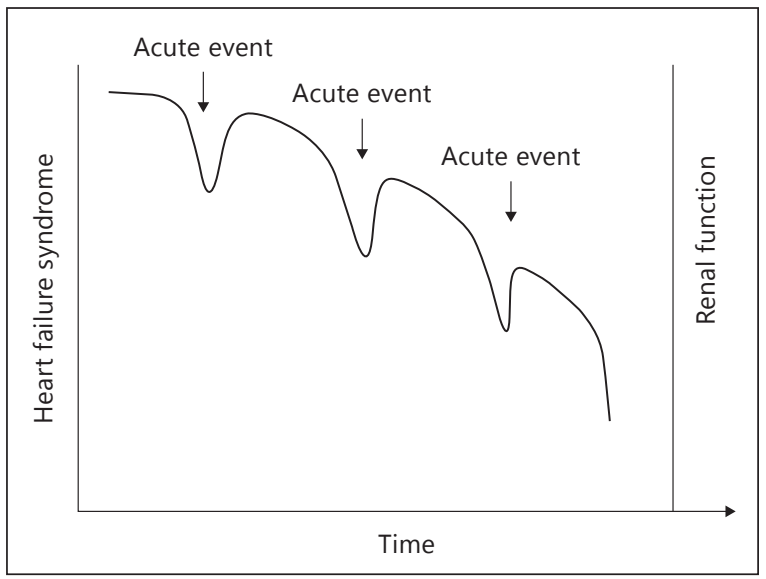

Fig. 3. Repeated acute events (HF decompensation and/or acute kidney injury) may contribute to the progression of chronic heart and kidney dysfunction. Reproduced with permission from ADQI [62]. 
model), there is increasing evidence of glomerular pathology as evidenced by albuminuria, podocyte injury and histological changes consistent with focal and segmental glomerulosclerosis. Variable decreases of glomerular filtration rate (GFR) have been reported in experimental chronic HF. Importantly, many of the changes appear to be related to systemic and local renal increases in sympathetic nervous system (SNS) and renin-angiotensin-aldosterone system (RAAS) activation.

One of the principle roles of a properly functioning cardiorenal axis is the maintenance of extracellular fluid volume homeostasis. A complex system of volume and pressure sensors, afferent and efferent feedback loops, local and distant vasoactive substances and neurohormonal systems with built-in redundancies serves to continuously monitor and adapt to changing extracellular fluid volume and blood pressure. When such systems are intact and working properly, they respond rapidly to ever-changing hemodynamics and volume status, and ensure adequate tissue perfusion and oxygen delivery. Some of the most important effector mechanisms include the SNS and RAAS.

In the setting of significant cardiac dysfunction, falling cardiac output and underfilling of the renal arterial tree results in activation of both SNS and RAAS [8]. It has long been recognized that the kidneys of patients with HF release substantial amounts of renin into the circulation [9], and this leads in turn to production of angiotensin II. Angiotensin II, working principally through the AT1 receptor, has broad-reaching effects. It is a powerful vasoconstrictor leading to increased systemic vascular resistance, venous tone and congestion, and has potent central nervous system effects on thirst, and activates the SNS. Angiotensin II also exerts significant effects on the kidneys stimulating tubular sodium reabsorption. Its powerful vasoconstrictive effects leads to preferential constriction of the efferent arteriole which in turn leads to increased glomerular filtration fraction, causing an increase in the oncotic pressure of the peritubular capillaries, enhancing the ability to return sodium and fluid to the circulation. The pivotal role of the RAAS system in this process has been demonstrated in animal models involving coronary artery ligation and subsequent infarction and HF [10] (table 1).

In support of clinical observational data implicating high venous pressure as an alternative and important cause of worsening GFR in HF, particularly with preserved ejection fraction and normal or high blood pressure, Kishimoto et al. [11] demonstrated in a dog model that renal venous hypertension, independent of changes in systemic arterial blood pressure, led not only to decreased renal blood flow and GFR, but also to increased renin release. This provides evidence for RAAS activation in the setting of HF characterized by venous hypertension and congestion, and not necessarily requiring decreased effective circulating volume as the stimulus. 
In addition to the maladaptive worsening of pressure and volume overload, the chronic activation of the SNS and RAAS is thought to contribute to the progression of CKD characteristic of CRS2. In an elegant animal model of chronic volume overload, Rafiq et al. [12] surgically induced aortic regurgitation in uninephrectomized rats and examined intrarenal levels of norepinephrine and angiotensin II, as well as albuminuria, renal function and histologic evidence of podocyte injury and reactive oxygen species production. They found that chronic volume overload led to predictable changes in the structure and function of the heart, with corresponding increases in both intrarenal SNS and RAAS activity, and that progressive kidney injury could be prevented by renal denervation and angiotensin receptor blockade. The authors propose that activation of the SNS and local angiotensin II stimulates NADPH oxidasedependent reactive oxygen species generation in the kidney, and these processes lead to podocyte injury and albuminuria.

Angiotensin II is also a potent stimulus for aldosterone release from the adrenal gland, leading to even further augmented sodium reabsorption in the distal nephron, contributing to pressure and volume overload. Moreover, aldosterone has been implicated in progression of CKD and renal fibrosis in a variety of clinical situations and through a number of mechanisms [13]. With an increased level of aldosterone in the kidney, pronounced oxidative stress occurs, via signaling from the paracrine glycoprotein galectin-3, pro-fibrotic cytokine transforming growth factor- $\beta$ (TGF- $\beta$ ) is upregulated, followed by increases in fibronectin, leading to renal fibrosis and glomerulosclerosis. With respect to CRS2, Onozato et al. [14] examined Dahl salt-sensitive HF rats where increased aldosterone was felt to contribute to worsening kidney function through increased oxidant stress and production of TGF- $\beta$. In this experiment, untreated animals with HF developed subsequent proteinuria, elevated creatinine and glomerulosclerosis with increased expression of NADPH oxidase, TGF- $\beta$ and fibronectin. They demonstrated that angiotensin-converting enzyme (ACE) inhibition and aldosterone blockade with eplerenone diminished oxidative stress, and TGF- $\beta$ was more effectively suppressed by aldosterone blockade than by ACE inhibition. The combination was able to prevent histologic renal damage, and lowered both creatinine and proteinuria to control levels. It needs to be noted that this model did not separate the effects of hypertension from those of CHF on the progression of kidney disease. Yet, it suggests an interplay of hypertension-induced and HF-associated renal injury with a related and mutually perpetuating pathophysiology.

Inflammation is an additional non-hemodynamic mechanism postulated in the progression of CKD in the setting of CHF. Inflammatory responses are designed to provide protection and promote healing in disease states. Cardiac 
myocytes, under the stress of mechanical stretch or ischemia, are capable of producing a broad array of inflammatory cytokines and invoking elements of the innate immune response [15]. Furthermore, venous congestion may increase gut absorption of endotoxin leading to additional inflammatory responses - while venous congestion itself is a stimulus for peripheral synthesis and release of inflammatory mediators [16]. Clinical evidence for this pro-inflammatory state comes from observations that patients with severe HF have markedly elevated levels of tumor necrosis factor (TNF)- $\alpha$, upregulation of soluble receptors for TNF, and a number of interleukins (IL) including IL-1 $\beta$, IL-18 and IL-6, as well as several cellular adhesion molecules.

It is conceivable that these systemic responses to HF could contribute to distant organ damage in the kidneys, though direct evidence for this cardiorenal link is only now emerging. In an acute myocardial infarction model in mice, $\mathrm{Lu}$ et al. [17] induced significant suppression of LV function accompanied by a marked pro-oxidant and pro-inflammatory state. These animals demonstrated evidence of CRS type 1, with acute rise in creatinine, however kidney dysfunction did not return to baseline, and histologically the kidneys were found to express a variety of pro-inflammatory molecules, pro-interleukin-1b (IL-1b), vascular cell adhesion molecule-1 (VCAM-1), and TGF- $\beta$. Early changes included inflammatory cellular infiltrates, while animals sacrificed later in the course of study demonstrated perivascular, periglomerular and peritubular fibrosis with increased markers of collagen formation, consistent with the human phenotype of CRS2. Knockout mice with a deletion that prevents production of the proinflammatory molecule lectin-like oxidized low-density lipoprotein receptor-1 (LOX-1), demonstrated significant abrogation of these responses, with improved renal and cardiac function and morphology.

In a rat model of CRS2 [18], rats with underlying kidney dysfunction were subjected to left anterior descending coronary artery ligation, and further progression of advanced CKD ensued over 30 days of follow-up. HF rats demonstrated marked increases in biomarkers of renal injury neutrophil gelatinaseassociated lipocalin (NGAL) and kidney injury molecule 1 (KIM-1), as well as patchy atrophic scarring with prominent clusters of $\mathrm{CD} 3+$ and $\mathrm{CD} 68+$ immune cells and significant interstitial fibrosis in renal tissue. In another rat model of CRS2, Lekawanvijit et al. [19] likewise performed left anterior descending coronary artery ligation to induce HF, and sacrificed animals after 16 weeks of chronic CHF. They also found increased expression of KIM-1 as well as the intracellular transcription factor phosphorylated Smad2, IL-6 and TGF- $\beta$ in the HF animals. Associated with these inflammatory markers were infiltrates with CD68+ immune cells, and significant interstitial fibrosis. Similarly, in a rat model of right HF secondary to monocrotaline-induced pulmonary hypertension 
and characterized by venous congestion, Angelini et al. $[20,21]$ demonstrated at the same time neurohormonal activation with increased levels of BNP, angiotensin II and inflammation. Pro-inflammatory cytokines (IL-1 $\alpha, \beta$, IL-2, IL-4, IL-6, IL-10, TNF- $\alpha$ ) were significantly increased and apoptosis was observed in the heart, lung, skeletal muscle, as well as in the vascular smooth muscle, tubular and glomerular cells of the kidney [Vescovo, pers. commun.]. In this model, NGAL detected by mRNA tissue extraction was also significantly increased in the HF rats compared to controls.

\section{Clinical Studies and Pathophysiological Insights into CRS2}

Data in humans provide support for these findings from animal studies. In a small autopsy study of 8 patients with CHF-related renal dysfunction, renal tissue also showed increased interstitial fibrosis, CD68+ immune cells and markers of oxidative stress (Rac1 expression and protein nitrosylation) [22]. Peritubular capillaries were dilated by $35 \%$, believed to be indicative of increased venous pressure in the kidney. In other larger studies, increased central venous or right atrial pressures were associated with impaired renal function and independently related to all-cause mortality in a broad spectrum of patients with cardiovascular disease, including acute and chronic HF [23-25]. This relationship was more pronounced when reduced renal perfusion was also present [25]. As suggested by animal studies, the raised central venous pressure may be transmitted backwards to the renal veins raising renal interstitial pressure, and resulting in subsequent systemic and intra-renal activation of the RAAS and SNS.

Clinical trials in which specific pathophysiologic mechanisms were the therapeutic targets also serve as an important resource for understanding the mechanisms of CRS2. Unfortunately, large randomized clinical trials in CHF focus on cardiovascular mortality and adverse cardiac events, and renal outcomes are usually reported as safety endpoints, if at all. A limited number of studies reported on long-term changes in creatinine or GFR, micro- or macroalbuminuria or other aspects relevant to kidney damage such as markers of fibrosis or of inflammation, some as post hoc analyses (table 2).

Several studies have been carried out in chronic HF aimed to block the RAAS. These have been done both with ACE inhibitors (ACEIs) and angiotensin II receptor blockers (ARBs). The drugs most extensively studied have been enalapril and captopril for ACEIs and valsartan and candesartan for ARBs. In the SOLVD study of enalapril in CHF, the net deterioration of eGFR from baseline to 14 days was slightly greater in the enalapril group compared to 
Table 2. Selected clinical trials on chronic heart failure and renal outcomes

\begin{tabular}{|c|c|c|c|c|}
\hline Mechanism & Agent & Study & Study population & $\begin{array}{l}\text { CKD patients } \\
\text { excluded, yes/no }\end{array}$ \\
\hline \multirow[t]{5}{*}{$\begin{array}{l}\text { RAAS } \\
\text { activation } \\
\text { ACEIs/ } \\
\text { ARBS }\end{array}$} & \multirow[t]{2}{*}{ Enalapril } & $\begin{array}{l}\text { Capes, } 2000 \\
\text { SOLVD trial } \\
\text { Testani, 2011, } \\
\text { SOLVD }\end{array}$ & $\begin{array}{l}\text { Clinically stable CHF } \\
(\text { LVEF <35\%) } \\
(n=6,700)\end{array}$ & no \\
\hline & & $\begin{array}{l}\text { Ljungman, } 1992 \\
\text { CONSENSUS }\end{array}$ & $\begin{array}{l}\text { Heart failure NYHA IV } \\
(n=250)\end{array}$ & no \\
\hline & Captopril & $\begin{array}{l}\text { Hillege, } 2003 \\
\text { CATS }\end{array}$ & Post-MI (n = 298) & no \\
\hline & Valsartan & $\begin{array}{l}\text { Anand, } 2009 \\
\text { VALHEFT }\end{array}$ & $\begin{array}{l}\text { Symptomatic } \\
\text { heart failure } \\
E F<40 \%(n=5,000)\end{array}$ & $\begin{array}{l}\text { yes } \\
\mathrm{Cr}>2.5\end{array}$ \\
\hline & Candesartan & $\begin{array}{l}\text { Jackson, } 2009 \\
\text { CHARM-added }\end{array}$ & $\begin{array}{l}\text { Heart failure } \\
\text { NYHA II-IV } \\
\text { EF }<40 \%(n=2,500)\end{array}$ & no \\
\hline \multirow[t]{3}{*}{$\begin{array}{l}\text { SNS } \\
\text { activation } \\
\text { betablockers }\end{array}$} & Carvedilol & $\begin{array}{l}\text { Wali, } 2011 \\
\text { COPERNICUS } \\
\text { CAPRICORN }\end{array}$ & $\begin{array}{l}\text { Severe heart failure } \\
E F<25 \%(n=4,200)\end{array}$ & no \\
\hline & Bisoprolol & $\begin{array}{l}\text { Damman, } 2011 \\
\text { Castagno, } 2010 \\
\text { CIBIS II }\end{array}$ & $\begin{array}{l}\text { CHF NYHA III-IV } \\
\text { EF }<35 \%(n=2,660)\end{array}$ & $\begin{array}{l}\text { no, but substudy } \\
\text { conducted in patients } \\
\text { with } \mathrm{Cr}<3.4\end{array}$ \\
\hline & Nebivolol & $\begin{array}{l}\text { Cohen-Solal, } 2009 \\
\text { SENIORS }\end{array}$ & $\begin{array}{l}\text { Symptomatic CHF } \\
\text { Age }>70(n=2,100)\end{array}$ & $\begin{array}{l}\text { yes, excluded if } \mathrm{Cr} \\
>250 \mu \mathrm{mol} / \mathrm{l}\end{array}$ \\
\hline \multirow[t]{4}{*}{$\begin{array}{l}\text { Aldoste- } \\
\text { rone }\end{array}$} & \multirow[t]{2}{*}{$\begin{array}{l}\text { Spirono- } \\
\text { lactone }\end{array}$} & $\begin{array}{l}\text { Pitt, } 1999 \\
\text { Vardeny, } 2012 \\
\text { RALES }\end{array}$ & $\begin{array}{l}\text { CHF EF }<35 \% \\
(n=1,600)\end{array}$ & $\begin{array}{l}\text { yes, excluded if } \mathrm{Cr} \\
>2.5 \mathrm{mg} / \mathrm{dl}\end{array}$ \\
\hline & & $\begin{array}{l}\text { Zannad, } 2001 \\
\text { RALES }\end{array}$ & $\begin{array}{l}\text { Substudy on } \\
261 \text { patients }\end{array}$ & yes, excluded if $\mathrm{Cr}>2.5$ \\
\hline & \multirow[t]{2}{*}{ Eplerenone } & $\begin{array}{l}\text { Rossignol, } 2012 \\
\text { EPHESUS }\end{array}$ & $\begin{array}{l}\text { HF after MI } \\
\text { EF }<40 \%(n=6,600)\end{array}$ & no \\
\hline & & $\begin{array}{l}\text { Zannad, } 2011 \\
\text { EMPHASIS HF }\end{array}$ & $\begin{array}{l}\text { HF NYHA II } \\
E F<35 \%(n=2,700)\end{array}$ & no \\
\hline \multirow[t]{2}{*}{$\begin{array}{l}\text { Renal } \\
\text { hypoperfusion }\end{array}$} & $\begin{array}{l}\text { Cardiac } \\
\text { resynchro- } \\
\text { nization }\end{array}$ & $\begin{array}{l}\text { Boerrigter, } 2008 \\
\text { MIRACLE }\end{array}$ & $\begin{array}{l}\text { NYHA III-IV } \\
\text { EF35\% QRS }>0.13 \\
(n=600)\end{array}$ & no \\
\hline & $\begin{array}{l}\text { Left ventricle- } \\
\text { assisted device }\end{array}$ & Sandner, 2009 & $\begin{array}{l}\text { Advanced CHF } \\
\text { Bridge to } \operatorname{Tx}(n=86)\end{array}$ & no \\
\hline \multirow[t]{2}{*}{$\begin{array}{l}\text { Inflam- } \\
\text { mation }\end{array}$} & Infliximab & $\begin{array}{l}\text { Chung, } 2003 \\
\text { ATTACH }\end{array}$ & $\begin{array}{l}\text { CHF NYHA III-IV } \\
\text { EF }<35 \%(n=150)\end{array}$ & no \\
\hline & Etanercept & $\begin{array}{l}\text { Mann, } 2004 \\
\text { RENEWAL }\end{array}$ & $\begin{array}{l}\text { CHF NYHA III-IV } \\
\text { EF }<30 \% \\
(n=2,048)\end{array}$ & no \\
\hline
\end{tabular}




\begin{tabular}{|c|c|c|}
\hline $\begin{array}{l}\text { Primary endpoint/ } \\
\text { duration of follow-up }\end{array}$ & $\begin{array}{l}\text { Renal outcomes } \\
\text { Cr/eGFR }\end{array}$ & Albuminuria \\
\hline $\begin{array}{l}\text { Composite of CV death } \\
\text { and re-admission for }\end{array}$ & Not stated & $\begin{array}{l}\text { Decreased proteinuria in diabetic patients, } \\
\text { not in non-diabetics }\end{array}$ \\
\hline $\mathrm{HF} / 48$ months & $\begin{array}{l}14 \text { days decline GFR }>20 \% \text { exited in } 20 \% \\
\text { increase mortality }\end{array}$ & Not stated \\
\hline $\begin{array}{l}\text { Crude mortality } \\
6 \text { months }\end{array}$ & Average initial increase $\mathrm{Cr} 10-15 \%$ & Not stated \\
\hline $\begin{array}{l}\text { Echo ventricular } \\
\text { remodeling } 1 \text { year }\end{array}$ & $\begin{array}{l}\text { Decline GFR } 5.5 \text { in placebo and } 0.5 \text { in } \\
\text { captopril }\end{array}$ & Not stated \\
\hline $\begin{array}{l}\text { Mortality }+ \text { first morbid } \\
\text { event } 1,000 \text { days }\end{array}$ & $\begin{array}{l}\text { Slight decrease in GFR in valsartan } \\
(-3.9 \text { vs. placebo })\end{array}$ & $\begin{array}{l}\text { Proteinuria associated with } 28 \% \text { increased } \\
\text { mortality }\end{array}$ \\
\hline $\begin{array}{l}\text { CV death } \\
\text { Hospital admission } \\
41 \text { months }\end{array}$ & Not stated & $\begin{array}{l}62 \% \text { increased death in patients with microal- } \\
\text { buminuria and } 76 \% \text { with macroalbuminuria. } \\
\text { Candesartan did not prevent excessive excreti- } \\
\text { on of urinary proteins }\end{array}$ \\
\hline
\end{tabular}

\begin{tabular}{lll}
\hline $\begin{array}{l}\text { All-cause mortality and } \\
\text { hospitalization }\end{array}$ & $\begin{array}{l}\text { Transient increase in serum creatinine } \\
\text { more common with carvedilol (4.6 vs. 1.8\% } \\
\text { in placebo, } \mathrm{p}<0.001) \text { among CKD patients }\end{array}$ & Not stated \\
\hline $\begin{array}{l}\text { All-cause mortality } \\
\text { hospitalization }\end{array}$ & Not stated & Not stated \\
18 months & & \\
\hline
\end{tabular}

\begin{tabular}{lll}
\hline $\begin{array}{l}\text { All-cause mortality } \\
\text { hospitalization } 30 \text { months }\end{array}$ & $\begin{array}{l}\text { No difference in } \triangle \mathrm{eGFR} \text { between nebivolol } \\
\text { and placebo }\end{array}$ & Not stated
\end{tabular}

Death of any cause $36 \quad$ WRF 17\% in spironolactone vs. 7\% placebo Not stated months but risk of death maintained $\mathrm{Cr}$ increase 0.05 to 0.1 after 1 year follow-up

Death of any cause 36 Not stated Not stated months

Other: markers of collagen synthesis (PINP PICP PIIINP) decreased with spironolactone

\begin{tabular}{|c|c|c|}
\hline $\begin{array}{l}\text { All deaths hospitalization } \\
24 \text { months }\end{array}$ & $\begin{array}{l}\text { Cr increase } 0.06 \text { after } 1 \text { year } \\
4.6 \text { after } 2 \text { years vs. placebo } 2.7\end{array}$ & Not stated \\
\hline $\begin{array}{l}\text { All deaths hospitalization } \\
21 \text { months }\end{array}$ & Cr increase 0.09 at trial cut-off & Not stated \\
\hline $\begin{array}{l}\text { Improved, unchanged, } \\
\text { worsened symptom score } \\
12 \text { months }\end{array}$ & $\begin{array}{l}\text { GFR increased } 2.7 \text { in patients with GFR } \\
30-60\end{array}$ & Not stated \\
\hline Renal function 6 months & $\begin{array}{l}\text { Renal function improves after LVAD } \\
\text { implantation }\end{array}$ & Not stated \\
\hline $\begin{array}{l}\text { Improvement clinical } \\
\text { status (NYHA). Death, } \\
\text { hospitalization } 28 \text { weeks }\end{array}$ & Not stated & Not stated \\
\hline $\begin{array}{l}\text { Clinical status at } 24 \\
\text { weeks. Death, } \\
\text { hospitalization }\end{array}$ & Not stated & Not stated \\
\hline
\end{tabular}


placebo. While early worsening of renal function was associated with increased mortality in the placebo group, it was free from adverse prognostic significance in the enalapril group [26]. In the same study, diabetic patients showed a decreased proteinuria with enalapril treatment [27]. An additional multivariable analysis suggested that despite a higher incidence of early worsening renal function in the enalapril group, there was no risk of longer term deterioration of eGFR compared with placebo [28]. In the CONSENSUS trial, patients randomized to enalapril showed an average increase in creatinine of $10-15 \%$ [29]. Hillege et al. [30] in post-MI patients with HF, although they observed a general deterioration of renal function after the acute event, reported that captopril preserved GFR when compared to placebo. In the VALHEFT trial a slight decrease in GFR in valsartan patients was observed ( -3.9 vs. placebo). The presence of dipstick proteinuria was associated with a $28 \%$ increase in mortality risk [31]. In the CHARM-Added trial with candesartan, a 62 and 76\% increased risk of death was observed in patients with micro- and macroalbuminuria, respectively. Candesartan did not prevent proteinuria [32]. Together, the current state of published evidence remains inconclusive regarding the role of ACEIs or ARBs in the prevention of the progression of CRS2.

CHF treatment with direct inhibitors of aldosterone receptors brought about a significant improvement in terms of survival and hospitalizations. Available data on spironolactone in the RALES trial showed worsening renal function in $17 \%$ of treated patients versus $7 \%$ in the placebo group, but the benefits on mortality were present in spite of this. Creatinine increased by approximately $0.05-0.1 \mathrm{mg} / \mathrm{dl}$ after 1 year follow-up in the spironolactone group with no significant change in the placebo group [33]. In the EPHESUS trial with eplerenone in post-MI patients with CHF, a creatinine increase of $0.06 \mathrm{mg} / \mathrm{dl}$ was observed after 1 year and $4.6 \mathrm{mg} / \mathrm{dl}$ after 2 years, while the placebo group had only an increase of $2.7 \mathrm{mg} / \mathrm{dl}$. In the EPHESUS trial, eplerenone produced a $0.09 \mathrm{mg} / \mathrm{dl}$ increase in creatinine at trial cut-off [34-36]. A decrease in surrogate markers of collagen synthesis (PINP, PICP, PIIINP) after spironolactone treatment suggests that fibrosis could be reduced after anti-aldosterone treatment [37].

It is important to note that a slight, expected, increase in creatinine, particularly in trials with inhibitors of RAAS, does not necessarily mean a progression of the CRS2. Data on survival, symptoms, exercise capacity, proteinuria or albuminuria are clearly visible with these drugs despite a small increase in serum creatinine. It is likely that serum creatinine, as a marker for GFR, is an inadequate biomarker for actual progression of disease given the difficulty in differentiating true progressive CKD from hemodynamic (and therefore potentially reversible) changes in GFR due to RAAS blockade and effects on filtration fraction. 
$\beta$-Blockers have become first-line treatment for CHF after the publication of COPERNICUS, CAPRICORN and CIBIS trials. In a meta-analysis of the CAPRICORN and COPERNICUS studies, carvedilol was associated with an increased relative incidence in transient increase in serum creatinine without need for dialysis ( 4.6 vs. $1.8 \%$ in placebo, $\mathrm{p}<0.001$ ) among CKD patients [38]. In the CIBIS trial, GFR was shown to be lower in patients with congestion. Bisoprolol showed greater benefits in patients with CKD $($ GFR <45) compared to placebo [39] and in this trial $\beta$-blocker treatment did not show any increase in serum creatinine. In elderly patients, nebivolol treatment did not modify GFR [40]. Overall there is inconsistency in the data on impact of $\beta$-blockers on creatinine in these trials.

Inflammation has been shown to play an important rolein the pathophysiology of HF both in terms of progression of cardiac damage and deterioration of the clinical status. Inflammation also plays an important role in the pathogenesis of kidney damage and progression of deterioration of renal function. This observation led several investigators to use TNF- $\alpha$ inhibitors in the treatment of HF. The results of several trials with infliximab or etanercept have been rather disappointing. Indeed either futility or excessive mortality have been shown with these drugs, despite an observed decrease in plasma levels of hsCRP and IL-6. This is corroborated by the results of the ATTACH, RECOVER and RENASSAINCE (RENEWAL) trials [41, 42]. However there are no reports in these trials of renal function.

Hypoperfusion in HF can be improved with cardiac resynchronization or left ventricular assist devices. In one study, cardiac resynchronization increased GFR by $2.7 \mathrm{ml} / \mathrm{min}$ in the subgroup of patients with GFR between 30 and 60 [43]. Sandner et al. [44] showed that renal function improves after left ventricular assist device implantation for bridging to cardiac transplantation. In an observational study on 10 children with cyanotic congenital heart disease, urinary excretion of albumin and markers of tubular injury, such as brush-border leucine-aminopeptidase and lysosomal N-acetyl- $\beta$-D-glucosaminidase (NAG) decreased significantly after palliative heart surgery. This was paralleled by an improvement in oxygen saturation levels and a decrease in hematocrit to nearnormal levels [45].

\section{Biomarkers of Renal Function}

To date, assessment of renal dysfunction in clinical HF studies has been largely limited to traditional biomarkers such as creatinine (or its derivative, eGFR) and urine protein and albumin excretion. In CHF, both impaired renal func- 
Table 3. Selected studies on novel renal biomarkers in chronic heart failure

\begin{tabular}{|c|c|c|c|c|}
\hline Study & $\begin{array}{l}\text { Study } \\
\text { population }\end{array}$ & Specimen & Biomarker & $\begin{array}{l}\text { HF vs. control } \\
\text { subjects }\end{array}$ \\
\hline Tang, 2008 & $\begin{array}{l}\text { Clinically stable CHF outpatients } \\
(n=139)\end{array}$ & Plasma & Cystatin C & No controls \\
\hline \multirow{3}{*}{$\begin{array}{l}\text { Damman, 2008, } \\
2010\end{array}$} & \multirow{3}{*}{$\begin{array}{l}\text { Clinically stable CHF outpatients } \\
(n=90)\end{array}$} & \multirow[t]{3}{*}{ Urine } & NGAL & $\mathrm{HF}>$ controls \\
\hline & & & NAG & $\mathrm{HF}>$ controls \\
\hline & & & KIM-1 & $\mathrm{HF}>$ controls \\
\hline \multirow[t]{3}{*}{ Jungbauer, 2011} & \multirow[t]{3}{*}{$\mathrm{CHF}(n=173)$} & \multirow[t]{3}{*}{ Urine } & NGAL & \\
\hline & & & NAG & \\
\hline & & & KIM-1 & $\mathrm{HF}>$ controls \\
\hline \multirow[t]{3}{*}{ Poniatowski, 2009} & \multirow[t]{3}{*}{ CHF due to CAD $(n=150)$} & Serum & $\begin{array}{l}\text { NGAL } \\
\text { Cystatin C }\end{array}$ & \multirow[t]{3}{*}{ No controls } \\
\hline & & \multirow[t]{2}{*}{ Urine } & NGAL & \\
\hline & & & Cystatin C & \\
\hline Bolignano, 2009 & $\begin{array}{l}\text { CHF (elderly, age }>65 \text { years }) \\
(n=46)\end{array}$ & Serum & NGAL & $\mathrm{HF}>$ controls \\
\hline Yndestad, 2009 & $\mathrm{CHF}(\mathrm{n}=150)$ & Serum & NGAL & $\mathrm{HF}>$ controls \\
\hline Shrestha, 2011 & CHF $($ LVEF $\leq 35 \%)(n=130)$ & Plasma & NGAL & No controls \\
\hline $\begin{array}{l}\mathrm{CAD}=\text { Coronary ar } \\
\mathrm{HF}=\text { heart failure; }\end{array}$ & $\begin{array}{l}\text { ry disease; } \mathrm{CHF}=\text { chronic heart fa } \\
5=\text { not stated. }\end{array}$ & $\mathrm{re} ; \mathrm{Cr}=\mathrm{cre}$ & ; GFR = glon & r filtration rate; \\
\hline
\end{tabular}

tion (as indicated by elevated creatinine or decreased eGFR) and increased urinary albumin excretion are powerful and independent predictors of prognosis $[32,46]$. Both are associated with heightened risk for death, cardiovascular death, and hospitalization, in patients with both preserved as well as reduced LVEF. In CKD, the level of eGFR and albuminuria has been shown to be prognostic of long-term renal outcomes $[47,48]$; this has not been demonstrated in CHF [49]. More recently, novel renal biomarkers, such as cystatin C (CysC), NGAL, KIM-1, and NAG have also been studied in CHF patients [50-57] (table 3). In many, but not all, studies, levels of these biomarkers are modestly elevated in CHF compared to control subjects, even among those with apparently normal renal function. While some of these biomarkers appear to have some prognostic properties with regard to adverse cardiovascular events, no study has looked at long-term change in renal function as an outcome.

Plasma CysC, believed to be a more sensitive marker of impaired GFR compared to creatinine, has been reported as an independent predictor of death, 


\begin{tabular}{|c|c|c|c|}
\hline \multicolumn{3}{|c|}{ Biomarker correlates with (in HF patients only) } & \multirow[t]{2}{*}{ Renal outcomes } \\
\hline renal function & clinical HF severity & natriuretic peptides & \\
\hline Yes & Yes & Yes & NS \\
\hline No & NS & No & NS \\
\hline Yes & NS & Yes & NS \\
\hline No & NS & Yes & NS \\
\hline $\begin{array}{l}\text { Yes, with albuminuria } \\
\text { No, with } \mathrm{Cr} / \mathrm{eGFR}\end{array}$ & No & No & No association with diuretic dose \\
\hline Yes & Yes & Yes & $\begin{array}{l}\text { Elevated in patients on higher } \\
\text { (vs. lower) diuretic doses }\end{array}$ \\
\hline $\begin{array}{l}\text { Yes, with albuminuria } \\
\text { No, with } \mathrm{Cr} / \mathrm{eGFR}\end{array}$ & Yes & Yes & $\begin{array}{l}\text { Elevated in patients on higher } \\
\text { (vs. lower) diuretic doses }\end{array}$ \\
\hline Yes & Yes & NS & NS \\
\hline Yes & NS & NS & NS \\
\hline Yes & Yes & NS & NS \\
\hline NS & NS & NS & NS \\
\hline No & Yes & NS & NS \\
\hline NS & Yes & Yes & NS \\
\hline Yes & Yes & Yes & \\
\hline
\end{tabular}

cardiac transplantation and HF hospitalizations [52, 54]. CysC also correlated with NT-pro-BNP levels and measures of LV dysfunction [52]. Studies assessing urinary CysC levels in CHF populations are currently lacking.

Recently, a systematic review summarized studies on NGAL in a spectrum of cardiovascular diseases, including CHF [50]. Animal and human tissue studies demonstrated that NGAL is highly expressed in failing myocardium and myocarditis, and it is also expressed in atherosclerotic plaques. Data on NGAL in a CRS2 rat model have been also been discussed above [18]. In clinical studies, blood and urine NGAL levels generally correlate with creatinine or eGFR; they also correlate with clinical and biochemical markers (e.g. natriuretic peptides) of HF severity in some, but not all, studies [50]. Systemic NGAL levels have also been associated with increased mortality and HF hospitalization [50, $53,55,58,59]$.

Analogous findings have also been reported for NAG and KIM-1. Urine levels of KIM-1, but not NAG or NGAL, are elevated in symptomatic HF compared to controls [60]. KIM-1 and NAG levels correlated with severity of 
$\mathrm{HF}$, and were also predictors of all-cause mortality and HF hospitalization on survival curve analysis. In 2,130 patients participating in the GISSI-HF trial, CHF patients who experienced a composite outcome of death or HF hospitalization had a significantly lower eGFR and a significantly higher urinary excretion of albumin, NAG, KIM-1, and NGAL [53]. On multivariable regression, the strongest association was seen with urinary NAG.

Although data on novel renal biomarkers in CHF is limited to date, they have great potential to enhance our understanding of CRS2 pathophysiology and should be evaluated in future large randomized controlled trials in HF. Indeed, the MinerAlocorticoid Receptor Antagonist Tolerability Study (ARTS) will examine the effects of the non-steroidal, mineralocorticoid receptor antagonist BAY 94-8862 on biomarkers of cardiac and renal function and injury, including the natriuretic peptides, KIM-1, NGAL, and CysC [61]. Results from this small study will undoubtedly inform future CRS2 trials.

\section{Conclusion}

In CRS2, the HF temporally precedes the occurrence or progression of CKD, and the manifestation and degree of kidney disease is plausibly explained by the underlying heart condition. Multiple and complex mechanisms have been proposed for CRS2; the most predominant being systemic and local renal increases in SNS and RAAS activation, hemodynamic factors of renal hypoperfusion and venous congestion, and inflammatory pathways. Animal models provide important insight into the pathogenesis of CRS2 by mimicking human phenotypes. Of the multitude of randomized controlled trials in CHF, relatively few reported long-term renal outcomes. While increased risk of kidney functional decline has been reported in some studies of RAAS inhibitors, most of the difference seen at the end of follow-up appeared to be attributable to the early treatment period. To date, renal outcomes have been largely limited to traditional biomarkers such as creatinine, eGFR, and urinary albumin excretion. Novel renal biomarkers appear to have some prognostic properties with regard to adverse cardiovascular events in CHF patients, but no study has looked at long-term change in renal function as an outcome. Ongoing and future interventional trials incorporating biomarkers of cardiac and renal function and injury among the endpoints will enhance our understanding of the pathophysiologic mechanisms behind CRS2. 


\section{References}

$>1$ Heywood JT, Fonarow GC, Costanzo MR, Mathur VS, Wigneswaran JR, Wynne J: High prevalence of renal dysfunction and its impact on outcome in 118,465 patients hospitalized with acute decompensated heart failure: a report from the ADHERE database. J Card Fail 2007;13:422-430.

$\checkmark 2$ Hebert K, Dias A, Delgado MC, Franco E, Tamariz L, Steen D, Trahan P, Major B, Arcement LM: Epidemiology and survival of the five stages of chronic kidney disease in a systolic heart failure population. Eur J Heart Fail 2010;12:861-865.

3 Cruz DN, Bagshaw SM: Heart-kidney interaction: epidemiology of cardiorenal syndromes. Int J Nephrol 2010;2011:351291.

4 Bagshaw SM, Cruz DN, Aspromonte N, Daliento L, Ronco F, Sheinfeld G, Anker SD, Anand I, Bellomo R, Berl T, et al: Epidemiology of cardio-renal syndromes: workgroup statements from the 7th ADQI Consensus Conference. Nephrol Dial Transplant 2010; 25:1406-1416.

5 Setoguchi S, Stevenson LW, Schneeweiss S: Repeated hospitalizations predict mortality in the community population with heart failure. Am Heart J 2007;154:260-266.

6 Tanaka K, Ito M, Kodama M, Maruyama H, Hoyano M, Mitsuma W, Iino N, Hirono S, Okura Y, Gejyo F, et al: Longitudinal change in renal function in patients with idiopathic dilated cardiomyopathy without renal insufficiency at initial diagnosis. Circ J 2007; 71:1927-1931.

7 Chawla LS, Kimmel PL: Acute kidney injury and chronic kidney disease: an integrated clinical syndrome. Kidney Int 2012;82:516524.

-8 Bongartz LG, Cramer MJ, Doevendans PA, Joles JA, Braam B: The severe cardiorenal syndrome: 'Guyton revisited'. Eur Heart J 2005;26:11-17.

9 Merrill AJ, Morrison JL, Branno ES: Concentration of renin in renal venous blood in patients with chronic heart failure. Am J Med 1946;1:468.

$\checkmark 10$ Ichikawa I, Pfeffer JM, Pfeffer MA, Hostetter $\mathrm{TH}$, Brenner BM: Role of angiotensin II in the altered renal function of congestive heart failure. Circ Res 1984;55:669-675.
11 Kishimoto T, Maekawa M, Abe Y, Yamamoto $\mathrm{K}$ : Intrarenal distribution of blood flow and renin release during renal venous pressure elevation. Kidney Int 1973;4:259-266.

12 Rafiq K, Noma T, Fujisawa Y, Ishihara Y, Arai Y, Nabi AH, Suzuki F, Nagai Y, Nakano D, Hitomi H, et al: Renal sympathetic denervation suppresses de novo podocyte injury and albuminuria in rats with aortic regurgitation. Circulation 2012;125:1402-1413.

13 Remuzzi G, Cattaneo D, Perico N: The aggravating mechanisms of aldosterone on kidney fibrosis. J Am Soc Nephrol 2008; 19: 1459-1462.

14 Onozato ML, Tojo A, Kobayashi N, Goto A, Matsuoka H, Fujita T: Dual blockade of aldosterone and angiotensin II additively suppresses TGF- $\beta$ and NADPH oxidase in the hypertensive kidney. Nephrol Dial Transplant 2007;22:1314-1322.

15 Colombo PC, Ganda A, Lin J, Onat D, Harxhi A, Iyasere JE, Uriel N, Cotter G: Inflammatory activation: cardiac, renal, and cardio-renal interactions in patients with the cardiorenal syndrome. Heart Fail Rev 2012; 17:177-190.

16 Colombo PC, Onat D, Sabbah HN: Acute heart failure as 'acute endothelitis'-interaction of fluid overload and endothelial dysfunction. Eur J Heart Fail 2008;10:170-175.

17 Lu J, Wang X, Wang W, Muniyappa H, Deshmukh A, Hu C, Das K, Mehta JL: Abrogation of lectin-like oxidized LDL receptor-1 attenuates acute myocardial ischemia-induced renal dysfunction by modulating systemic and local inflammation. Kidney Int 2012;82:436-444.

18 Entin-Meer M, Ben-Shoshan J, MayselAuslender S, Levy R, Goryainov P, Schwartz I, Barshack I, Avivi C, Sharir R, Keren G: Accelerated renal fibrosis in cardiorenal syndrome is associated with long-term increase in urine neutrophil gelatinaseassociated lipocalin levels. Am J Nephrol 2012;36:190-200.

19 Lekawanvijit S, Kompa AR, Zhang Y, Wang BH, Kelly DJ, Krum H: Myocardial infarction impairs renal function, induces renal interstitial fibrosis, and increases renal KIM1 expression: implications for cardiorenal syndrome. Am J Physiol Heart Circ Physiol 2012;302:H1884-H1893. 
20 Angelini A, Castellani C, Ravara B, Franzin C, Pozzobon M, Tavano R, Libera LD, Papini E, Vettor R, De Coppi P, et al: Stem-cell therapy in an experimental model of pulmonary hypertension and right heart failure: role of paracrine and neurohormonal milieu in the remodeling process. J Heart Lung Transplant 2011;30:1281-1293.

21 Dalla Libera L, Ravara B, Angelini A, Rossini K, Sandri M, Thiene G, Battista Ambrosio G, Vescovo G: Beneficial effects on skeletal muscle of the angiotensin II type 1 receptor blocker irbesartan in experimental heart failure. Circulation 2001;103:21952200.

-22 Tanaka M, Yoshida H, Furuhashi M, Togashi N, Koyama M, Yamamoto S, Yamashita T, Okazaki Y, Ishimura S, Ota H, et al: Deterioration of renal function by chronic heart failure is associated with congestion and oxidative stress in the tubulointerstitium. Intern Med 2011;50:2877-2887.

23 Damman K, van Deursen VM, Navis G, Voors AA, van Veldhuisen DJ, Hillege HL: Increased central venous pressure is associated with impaired renal function and mortality in a broad spectrum of patients with cardiovascular disease. J Am Coll Cardiol 2009;53:582-588.

-24 Mullens W, Abrahams Z, Francis GS, Sokos G, Taylor DO, Starling RC, Young JB, Tang WHW: Importance of venous congestion for worsening of renal function in advanced decompensated heart failure. J Am Coll Cardiol 2009;53:589-596.

25 Damman K, Navis G, Smilde TD, Voors AA, van der Bij W, van Veldhuisen DJ, Hillege HL: Decreased cardiac output, venous congestion and the association with renal impairment in patients with cardiac dysfunction. Eur J Heart Fail 2007;9:872-878

-26 Testani JM, Kimmel SE, Dries DL, Coca SG: Prognostic importance of early worsening renal function after initiation of angiotensinconverting enzyme inhibitor therapy in patients with cardiac dysfunction. Circ Heart Fail 2011;4:685-691.

-27 Capes SE, Gerstein HC, Negassa A, Yusuf S: Enalapril prevents clinical proteinuria in diabetic patients with low ejection fraction. Diabetes Care 2000;23:377-380.
28 Bansal N, Tighiouart H, Weiner D, Griffith J, Vlagopoulos P, Salem D, Levin A, Sarnak MJ: Anemia as a risk factor for kidney function decline in individuals with heart failure. Am J Cardiol 2007;99:1137-1142.

29 Ljungman S, Kjekshus J, Swedberg K: Renal function in severe congestive heart failure during treatment with enalapril - the Cooperative North Scandinavian Enalapril Survival Study (CONSENSUS) Trial. Am J Cardiol 1992;70:479-487.

30 Hillege HL, van Gilst WH, van Veldhuisen DJ, Navis G, Grobbee DE, de Graeff PA, de Zeeuw D: Accelerated decline and prognostic impact of renal function after myocardial infarction and the benefits of ACE inhibition: the CATS randomized trial. Eur Heart J 2003; 24:412-420.

-31 Anand IS, Bishu K, Rector TS, Ishani A, Kuskowski MA, Cohn JN: Proteinuria, chronic kidney disease, and the effect of an angiotensin receptor blocker in addition to an angiotensin-converting enzyme inhibitor in patients with moderate to severe heart failure. Circulation 2009;120:1577-1584.

32 Jackson CE, Solomon SD, Gerstein HC, Zetterstrand S, Olofsson B, Michelson EL, Granger CB, Swedberg K, Pfeffer MA, Yusuf $\mathrm{S}$, et al: Albuminuria in chronic heart failure: prevalence and prognostic importance. Lancet 2009;374:543-550.

33 Pitt B, Zannad F, Remme WJ, Cody R, Castaigne A, Perez A, Palensky J, Wittes J: The effect of spironolactone on morbidity and mortality in patients with severe heart failure. Randomized Aldactone Evaluation Study Investigators. N Engl J Med 1999;341: 709-717.

34 Rossignol P, Cleland JG, Bhandari S, Tala S, Gustafsson F, Fay R, Lamiral Z, Dobre D, Pitt B, Zannad F: Determinants and consequences of renal function variations with aldosterone blocker therapy in heart failure patients after myocardial infarction: insights from the Eplerenone Post-Acute Myocardial Infarction Heart Failure Efficacy and Survival Study. Circulation 2012;125:271-279.

35 Zannad F, McMurray JJ, Krum H, van Veldhuisen DJ, Swedberg K, Shi H, Vincent J, Pocock SJ, Pitt B: Eplerenone in patients with systolic heart failure and mild symptoms. N Engl J Med 2011;364:11-21. 
-36 Zannad F, Gattis Stough W, Rossignol P, Bauersachs J, McMurray JJ, Swedberg K, Struthers AD, Voors AA, Ruilope LM, Bakris GL, et al: Mineralocorticoid receptor antagonists for heart failure with reduced ejection fraction: integrating evidence into clinical practice. Eur Heart J 2012;33:2782-2795.

37 Zannad F, Dousset B, Alla F: Treatment of congestive heart failure: interfering the aldosterone-cardiac extracellular matrix relationship. Hypertension 2001;38:12271232.

38 Wali RK, Iyengar M, Beck GJ, Chartyan DM, Chonchol M, Lukas MA, Cooper C, Himmelfarb J, Weir MR, Berl T, et al: Efficacy and safety of carvedilol in treatment of heart failure with chronic kidney disease: a meta-analysis of randomized trials. Circulation Heart failure 2011;4:18-26.

39 Castagno D, Jhund PS, McMurray JJ, Lewsey JD, Erdmann E, Zannad F, Remme WJ, Lopez-Sendon JL, Lechat P, Follath F, et al: Improved survival with bisoprolol in patients with heart failure and renal impairment: an analysis of the cardiac insufficiency bisoprolol study II (CIBIS-II) trial. Eur J Heart Fail 2010;12:607-616.

40 Cohen-Solal A, Kotecha D, van Veldhuisen DJ, Babalis D, Bohm M, Coats AJ, Roughton M, Poole-Wilson P, Tavazzi L, Flather M: Efficacy and safety of nebivolol in elderly heart failure patients with impaired renal function: insights from the SENIORS trial. Eur J Heart Fail 2009;11:872-880.

-41 Chung ES, Packer M, Lo KH, Fasanmade AA, Willerson JT: Randomized, double-blind, placebo-controlled, pilot trial of infliximab, a chimeric monoclonal antibody to tumor necrosis factor- $\alpha$, in patients with moderateto-severe heart failure: results of the antiTNF Therapy Against Congestive Heart Failure (ATTACH) trial. Circulation 2003; 107:3133-3140.

42 Mann DL, McMurray JJ, Packer M, Swedberg K, Borer JS, Colucci WS, Djian J, Drexler H, Feldman A, Kober L, et al: Targeted anticytokine therapy in patients with chronic heart failure: results of the Randomized Etanercept Worldwide Evaluation (RENEWAL). Circulation 2004;109:15941602.
43 Boerrigter G, Costello-Boerrigter LC, Abraham WT, Sutton MG, Heublein DM, Kruger KM, Hill MR, McCullough PA, Burnett JC Jr: Cardiac resynchronization therapy improves renal function in human heart failure with reduced glomerular filtration rate. J Card Fail 2008;14:539-546.

44 Sandner SE, Zimpfer D, Zrunek P, Rajek A, Schima H, Dunkler D, Grimm M, Wolner E, Wieselthaler GM: Renal function and outcome after continuous flow left ventricular assist device implantation. Ann Thorac Surg 2009;87:1072-1078.

45 Awad H, el-Safty I, Abdel-Gawad M, el-Said S: Glomerular and tubular dysfunction in children with congenital cyanotic heart disease: effect of palliative surgery. Am J Med Sci 2003;325:110-114.

46 Hillege HL, Nitsch D, Pfeffer MA, Swedberg K, McMurray JJ, Yusuf S, Granger CB, Michelson EL, Ostergren J, Cornel JH, et al: Renal function as a predictor of outcome in a broad spectrum of patients with heart failure. Circulation 2006;113:671-678.

47 Halbesma N, Jansen DF, Heymans MW, Stolk RP, de Jong PE, Gansevoort RT: Development and validation of a general population renal risk score. Clin J Am Soc Nephrol 2011;6:1731-1738.

48 Tangri N, Stevens LA, Griffith J, Tighiouart H, Djurdjev O, Naimark D, Levin A, Levey AS: A predictive model for progression of chronic kidney disease to kidney failure. JAMA 2011;305:1553-1559.

49 Khan NA, Ma I, Thompson CR, Humphries K, Salem DN, Sarnak MJ, Levin A: Kidney function and mortality among patients with left ventricular systolic dysfunction. J Am Soc Nephrol 2006;17:244-253.

50 Cruz DN, Gaiao S, Maisel A, Ronco C, Devarajan P: Neutrophil gelatinaseassociated lipocalin as a biomarker of cardiovascular disease: a systematic review. Clin Chem Lab Med 2012;50:1533-1545.

51 Cruz DN, Fard A, Clementi A, Ronco C, Maisel A: Role of biomarkers in the diagnosis and management of cardiorenal syndromes. Semin Nephrol 2012;32:79-92.

-52 Tang WH, Van Lente F, Shrestha K, Troughton RW, Francis GS, Tong W, Martin MG, Borowski AG, Jasper S, Starling RC, et al: Impact of myocardial function on cystatin $\mathrm{C}$ measurements in chronic systolic heart failure. J Card Fail 2008;14:394-399. 
53 Damman K, Masson S, Hillege HL, Maggioni AP, Voors AA, Opasich C, van Veldhuisen DJ, Montagna L, Cosmi F, Tognoni G, et al: Clinical outcome of renal tubular damage in chronic heart failure. Eur Heart J 2011;32: 2705-2712.

54 Damman K, van der Harst P, Smilde TD, Voors AA, Navis G, van Veldhuisen DJ, Hillege HL: Use of cystatin C levels in estimating renal function and prognosis in patients with chronic systolic heart failure. Heart 2012;98:319-324.

55 Damman K, van Veldhuisen DJ, Navis G, Vaidya VS, Smilde TD, Westenbrink BD, Bonventre JV, Voors AA, Hillege HL: Tubular damage in chronic systolic heart failure is associated with reduced survival independent of glomerular filtration rate. Heart 2010;96:1297-1302.

56 Damman K, van Veldhuisen DJ, Navis G, Voors AA, Hillege HL: Urinary neutrophil gelatinase associated lipocalin, a marker of tubular damage, is increased in patients with chronic heart failure. Eur J Heart Fail 2008; 10:997-1000.

57 Nymo SH, Ueland T, Askevold ET, Flo TH, Kjekshus J, Hulthe J, Wikstrand J, McMurray J, van Veldhuisen DJ, Gullestad L, et al: The association between neutrophil gelatinaseassociated lipocalin and clinical outcome in chronic heart failure: results from CORONA. J Intern Med 2012;271:436-443.
58 Bolignano D, Basile G, Parisi P, Coppolino G, Nicocia G, Buemi M: Increased plasma neutrophil gelatinase-associated lipocalin levels predict mortality in elderly patients with chronic heart failure. Rejuvenation Res 2009; 12:7-14.

59 Shrestha K, Borowski AG, Troughton RW, Thomas JD, Klein AL, Tang WH: Renal dysfunction is a stronger determinant of systemic neutrophil gelatinase-associated lipocalin levels than myocardial dysfunction in systolic heart failure. J Card Fail 2011;17: $472-478$.

60 Jungbauer CG, Birner C, Jung B, Buchner S, Lubnow M, von Bary C, Endemann D, Banas B, Mack M, Boger CA, et al: Kidney injury molecule- 1 and $\mathrm{N}$-acetyl- $\beta$-Dglucosaminidase in chronic heart failure: possible biomarkers of cardiorenal syndrome. Eur J Heart Fail 2011;13:1104-1110.

61 Pitt B, Filippatos G, Gheorghiade M, Kober L, Krum H, Ponikowski P, Nowack C, Kolkhof P, Kim SY, Zannad F: Rationale and design of ARTS: a randomized, double-blind study of BAY 94-8862 in patients with chronic heart failure and mild or moderate chronic kidney disease. Eur J Heart Fail 2012; 14:668-675.

62 Acute Dialysis Quality Initiative (ADQI). www.ADQI.org (accessed January 10, 2013).

Dinna N. Cruz, MD, MPH

Division of Nephrology-Hypertension

University of California, San Diego, 200 West Arbor Drive 8409

San Diego, CA 92103-8409 (USA)

E-Maildinnacruzmd@yahoo.com 